Article

\title{
Expression of POU2F3 Transcription Factor Control Inflammation, Immunological Recruitment and Metastasis of Pancreatic Cancer in Mice
}

\author{
Jennifer Bintz ${ }^{1}\left(\right.$, Analía Meilerman Abuelafia ${ }^{1}$, François Gerbe ${ }^{2}$, Elodie Baudoin ${ }^{3}$, \\ Nathalie Auphan-Anezin ${ }^{3}{ }^{-}$, Emmanuelle Sidot ${ }^{2}$, Philippe Jay ${ }^{2}$ and Juan Iovanna ${ }^{1, *}$ \\ 1 Centre de Recherche en Cancérologie de Marseille (CRCM), INSERM U1068, CNRS UMR 7258, Aix-Marseille \\ Université and Institut Paoli-Calmettes, Parc Scientifique et Technologique de Luminy, 13288 Marseille, \\ France; jennifer.bintz@free.fr or jennifer.bintz@bric.ku.dk (J.B.); meilerman.analia@gmail.com (A.M.A.) \\ 2 Institute of Functional Genomics (IGF), University of Montpellier, CNRS, INSERM, \\ Equipe Labellisee Ligue Contre le Cancer, 34000 Montpellier, France; Francois.Gerbe@igf.cnrs.fr (F.G.); \\ emmanuelle.sidot@kennedy.ox.ac.uk (E.S.); Philippe.Jay@igf.cnrs.fr (P.J.) \\ 3 Centre d'Immunologie de Marseille-Luminy, Aix-Marseille Université, INSERM U1104, CNRS UMR 7280, \\ Parc Scientifique et Technologique de Luminy, 13288 Marseille, France; elodie.baudoin@inserm.fr (E.B.); \\ auphan@ciml.univ-mrs.fr (N.A.-A.) \\ * Correspondence: juan.iovanna@inserm.fr; Tel.: +33-491828803
}

Received: 7 September 2020; Accepted: 16 October 2020; Published: 19 October 2020

Simple Summary: The presence and the role of TUFT cells in pancreatic ductal adenocarcinoma (PDAC) is discussed. Therefore, we decided to inactivate the POU2F3 gene, which is essential for TUFT cells development, in an aggressive PDAC mice model known as PDX1-Cre;LSL-Kras ${ }^{\mathrm{G} 12 \mathrm{D}}$;Ink4a $\mathrm{a}^{\mathrm{fl} / \mathrm{fl}}$. Morphological and molecular analysis of POU2F3-deleted PDAC show not significant changes in tumors growth and survival of animals although it promotes EMT. Remarkably, we observed that in POU2F3-deleted animals the lack of TUFT cells prevents metastasis formation and strongly modifies the immunological and inflammatory landscape.

\begin{abstract}
TUFT cells have been described as strong modulators of inflammatory cells in several tissues including pancreas. TUFT cells, also known as $\mathrm{DCLK} 1^{+}$cells, are dependent of the transcriptional factor POU2F3. Several works report DCLK1 ${ }^{+}$cells in early stages of PDAC development suggesting an important role of TUFT cells in PDAC development. Therefore, we developed a mice model (PDX1-Cre;Kras ${ }^{\mathrm{G} 12 \mathrm{D}}$;Ink4a ${ }^{\mathrm{fl} / \mathrm{fl}}$ ), known as PKI model, deficient or not of POU2F3. In this animal model, deficiency of POU2F3 results in the absence of TUFT cells in PDAC as expected. Although, tumor development and growth are not significantly influenced, the development of liver metastasis was almost completely inhibited in POU2F3-deficient mice. Surprisingly, the absence of metastasis was associated with a higher expression of epithelial-to-mesenchymal transition markers, but to a lower inflammatory microenvironment suggesting that inflammation influences metastasis production more than epithelial-to-mesenchymal transition in this animal model. We can conclude that POU2F3 could be a new therapeutic target for control PDAC progression.
\end{abstract}

Keywords: TUFT cells; POU2F3; PDAC; epithelial-to-mesenchymal transition; metastasis

\section{Introduction}

Pancreatic Ductal Adenocarcinoma (PDAC) is the fourth leading cause of death by cancer in western countries, while it is only the tenth in term of incidence according to the World Health Organisation. Those data illustrate how far we are from understanding the mechanisms of pancreatic 
cancer development and progression. At present, physicians are still unable to prevent it or even to propose an efficient treatment at the moment of its diagnosis. Indeed, alongside the absence of symptoms [1], chemo-resistance is another issue we have to face [2]. Moreover, with the rise of immunotherapies, new hopes are coming out and scientists attempt to detail the immune response against cancers in order to adapt and refine therapeutically strategies [3,4]. Unfortunately, these new therapies showing remarkable results in several cancers [5-7], are almost inefficient for treating patients with a PDAC nowadays. One of the most important reasons for the poor clinical evolution of patients suffering a PDAC is its very early metastatic capacity that kills patients [8]. Several factors are known to increase the metastatic capacity of cancer cells such as epithelial-to-mesenchymal transition [9], chemotactic factors [10], cytokines [11], adhesion molecules [12], and expression of some metalloproteinases [13], among other important factors. Another lesser-studied mechanism, likely involved, in metastasis of PDAC is inflammation [14,15]. Inflammation of PDAC is largely considered to promote PDAC and controls its aggressiveness. Although, the mechanism starting $[16,17]$ and maintaining inflammation in tumors remain poorly described.

TUFT cells have been described as strong modulators of inflammatory cells in several tissues $[18,19]$ including pancreas [20,21]. TUFT cells, also known as DCLK1+ cells [22], are dependent of the transcriptional factor POU2F3 [23,24]. In this way several papers report DCLK1+ cells in early stages of PDAC development such as ADM and PanIN [25-29] suggesting an important role of TUFT cells in PDAC development through inflammation. Therefore, we developed a mice model (PDX1-Cre;KrasG12D;Ink4aflox/flox), known as PKI model [30], in which an aggressive PDAC is genetically induced, deficient or not for POU2F3. In this model, deficiency of POU2F3 results in the absence of TUFT cells in PDAC as expected. Although, tumor growth is not significantly modified, development of liver metastasis was almost inhibited in POU2F3 deficient mice. Surprisingly, absence of metastasis was associated to a higher expression of epithelial-to-mesenchymal transition markers but to a lower inflammatory microenvironment suggesting that inflammation influences metastasis production more than epithelial-to-mesenchymal transition in this animal model. Therefore, POU2F3 could be a new therapeutic target for controlling PDAC progression.

\section{Materials and Methods}

\subsection{Animals}

The mouse model of pancreatic adenocarcinoma used in this study resulted from crossbreeding of the following strains: Pdx1-cre [31], LSL-KrasG12D6 and Ink4a/Arffl/fl [32,33]. POU2F3KO mice were previously reported [23]. The mice were kept in the Experimental Animal House of the Centre de Cancérologie de Marseille (CRCM) pole Luminy, following institutional guidelines.

\subsection{Immunohistochemistry}

Tissue dissection, fixation, and immunohistochemistry on thin sections of paraffin-embedded tissue were performed essentially as described previously. The antibodies used in this study were presented in Table S1. Slides were washed twice times with 0.1\% PBS-Tween (Sigma-Aldrich, Saint-Quentin Fallavier, France) before incubation with a secondary biotinylated antibody. Signals were developed with DAB (Sigma-Aldrich) and a haematoxylin counterstain (DiaPath) was used. After dehydration, sections were mounted in Pertex (Histolab). All experiments were performed on formalin-fixed tissues and $10 \mathrm{mM}$ sodium citrate ( $\mathrm{pH}$ 6.4) or Tris-EDTA ( $\mathrm{pH}$ 9.0) treatment was used. Every staining was repeated in 3 different experiments and performed upon 6 individual tumors.

\section{3. $R T-q P C R$}

RNAeasy Mini Kit (QIAGEN) has been used for the extraction and the purification of RNA from frozen tumors. Homogenization was performed right after adding the protein precipitation buffer with iron beads thanks to the Precellys Evolution device (OZYME). Supernatant from the 10.000 RPM 
centrifugation for $10 \mathrm{~min}$ was transferred into the column for purification. Then, we went through the Reverse Transcription (GoScript PROMEGA) from $1 \mu \mathrm{g}$ of RNA in order to get $20 \mu \mathrm{L}$ of cDNA diluted in $200 \mu \mathrm{L}$ of water before using $2 \mu \mathrm{L}$ into the qPCR Master Mix (GoTaq PROMEGA). Primers were as follow in Table S2.

\subsection{Immunophenotyping}

Warmed PBS (1 $\times, 3 \mathrm{mM}$ EDTA) has been injected into peritoneal cavity in order to aspirate the circulating cells. After centrifugation, the pellet is resuspended with a specific FACS buffer ( $1 \times$ PBS, $2 \%$ FCS, 1 mM EDTA, $0.1 \%$ sodium azyde). Organs were collected from mice and saved in DMEM medium (Life Technologies, Villebon sur Yvette, France) completed with 10\% FCS, Penicilline, Streptomycin, Glutamine, Pyruvate, Hepes and $\beta$ ME. For homogenization, tumors were first manually dissociated with scissors then with GentleMACS Dissociator (Milteny Biotec, Paris, France) according to the manufacturer's protocol. The spleen was smashed with a syringe and filtrated through nylon tissue. Counting through Malassez cell helped us to normalize every sample before the incubation with antibodies listed in the Table S3. Analysis has been performed with a flow cytometer (BD LSR Fortessa $\times 20$ ). Antibodies are mixed into blocking solution (24G2) before the incubation with the cells during $30 \mathrm{~min}$ at $4{ }^{\circ} \mathrm{C}$ then washed with FACS buffer. After centrifugation, cells are resuspended with PBS $1 \times$ with a viability marker then filtrated before Cytometer analysis.

\subsection{Study Approval}

All experimental protocols were carried out in accordance with the nationally approved guidelines for the treatment of laboratory animals. All experimental procedures on animals were approved by the Comité d'éthique de Marseille numéro 14 (n²018092011266070).

\subsection{Statistical Analysis}

Survival curves have been processed with PRISM software using the Kaplan-Meyer equation. Transcriptomic results are presented as the mean from 6 individual tumors in 3 independent experiments and have been tested according to the Mann-Whitney equation. The IHC sections come from the same individuals. Immunophenotyping have been performed with 3 independent individuals for each groups (POU2F3 ${ }^{-/}$and POU2F3 ${ }^{+/+}$) and tested with PRISM. Significance is evaluated with 1,2 or 3 stars for $p$-value below $0.05,0.01$ and 0.001 respectively.

\section{Results}

\subsection{TUFT Cells Are Not Essential for Pancreatic Carcinogenesis}

We evaluated the role of the TUFT cells in carcinogenesis of pancreatic cancer. To this end we developed an engineered mice (PDX1-Cre;KrasG12D;Ink4aflox/flox), known as PKI model, which develop an aggressive PDAC, deficient or not for POU2F3, a transcriptional factor which is known to control the development of TUFT cells. Specific staining of the POU2F3 protein was found in the nucleus of $6.80 \pm 2.12 \%$ of PDAC cells of PKI;POU2F3 ${ }^{+/+}$but not of PKI;POU2F3 ${ }^{-/-}$mice (Figure 1B). Moreover, DCLK1 protein expression was strongly detected in $8.25 \pm 3.20 \%$ of PDAC cells from PKI;POU2F3 ${ }^{+/+}$but not in the pancreas from PKI;POU2F3 ${ }^{-/-}$mice (Figure 1B). These results validate that TUFT cells development are dependent of the POU2F3 expression in pancreatic cancer like in intestine [23] and lung [24], but more importantly, they show that these cells were dispensable for PDAC development. We systematically euthanized these mice at the time presenting the first signs of agony or suffering (around 9 weeks olds). Tumors were immediately removed and weighed after sacrifice from both PKI;POU2F3 ${ }^{+/}$and PKI;POU2F3 ${ }^{-/}$mice. Tumors showed not differences in their weigh $(68 \pm 4.32 \mathrm{mg}$ vs. $76 \pm 5.10 \mathrm{mg} ; p$-value $=0.1)$ as shown in Figure $1 \mathrm{~A}$. The time of their sacrifice was respectively $8 \pm 0.88$ weeks and $9 \pm 0.22$ weeks olds for PKI;POU2F3 ${ }^{+/+}$and $\mathrm{PKI} ; \mathrm{POU} 2 \mathrm{~F}^{-/-}$mice (Figure 1A). 

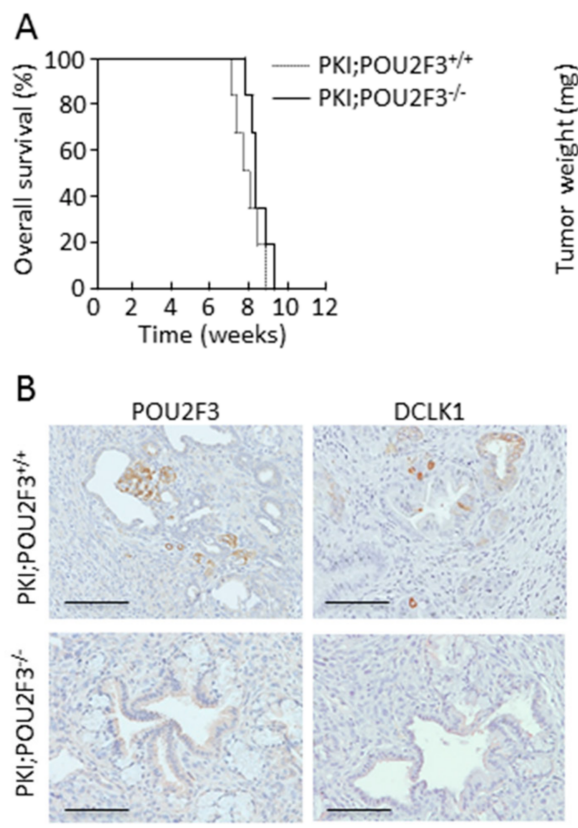
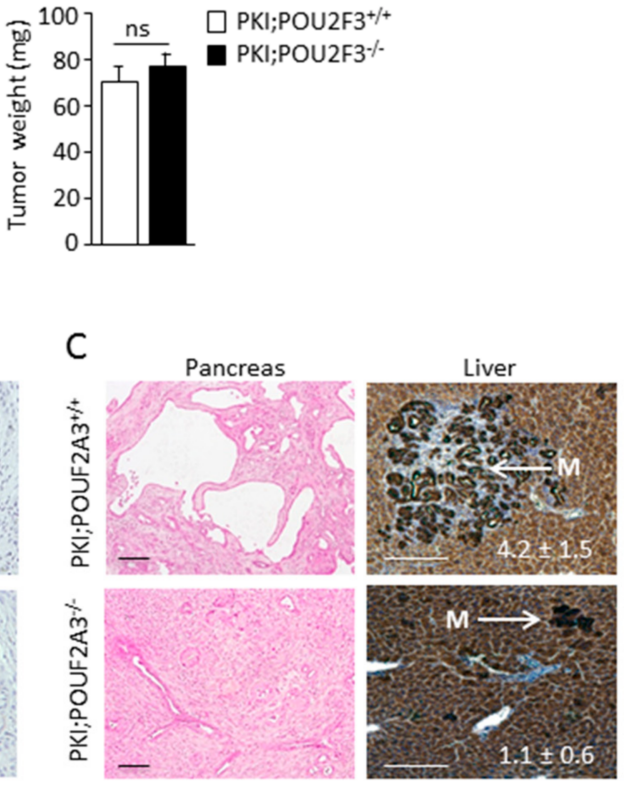

Figure 1. POU2F3 is not essential for pancreatic carcinogenesis but it is critical for liver metastasis. (A) Kaplan Meier survival curve of PKI;POU2F3 ${ }^{+/+}$and PKI;POU2F3 ${ }^{-/}$mice (left panel) and the tumor weight at the sacrifice time (right panel). (B) Immuno-staining of POU2F3 and DCLK1 in the pancreas from PKI;POU2F3 ${ }^{+/+}$and PKI;POU2F3 ${ }^{-/-}$mice. (C) Hematoxylin and Eosin staining of the pancreas and liver from PKI;POU2F3 ${ }^{+/+}$and PKI;POU2F3 ${ }^{-/-}$mice. Values denote the metastasis per liver. Scale set as $100 \mu \mathrm{m}$.

\subsection{POU2F3 Inactivation Decreases Liver Metastasis Development}

Although, PDAC growth is similar in PKI;POU2F3 ${ }^{+/+}$and PKI;POU2F3 ${ }^{-/-}$mice, we measured the metastatic capacity of these tumors to spread in liver. We obtained the livers of these animals and after the H\&E staining we estimated the number of microscopic metastasis. To our surprise almost not metastasis were found in livers from PKI;POU2F3 ${ }^{-/-}$mice. Livers from PKI;POU2F3 ${ }^{+/+}$ mice showed $4.2 \pm 1.5$ metastasis per liver whereas livers from PKI;POU2F3 ${ }^{-/}$mice showed only 1.1 \pm 0.6 as presented in Figure 1C. Interestingly, morphological characteristics of both PKI;POU2F3 ${ }^{+/+}$ and PKI;POU2F3 ${ }^{-/}$metastasis are similar in size and histology. We conclude that although POU2F3 deficiency does not influences tumor growth, it could play an essential role in metastasis development.

\subsection{POU2F3 Inactivation Enhances Epithelial-to-Mesenchymal Transition in PDAC}

Then, we wanted to characterize the histology of the PDAC from both PKI;POU2F3 ${ }^{+/+}$and PKI;POU2F3 ${ }^{-1-}$ mice. Thus, after tumors staining with H\&E we found PDAC presenting several large cystic-like structures with a monolayer of epithelial cells (Figure 1C) in PKI;POU2F3 ${ }^{+/+}$mice, previously described as high grade PanIN, and expressing abundant E-cadherin, also known as Cdh1 (Figure 2A). Surprisingly, those structures are not obvious in PKI;POU2F3-/- mice as shown in Figure 1C. On the contrary, in the PDAC from PKI;POU2F3-/- mice we are still able to describe every stage of PDAC development, with large cytoplasm and lack of nuclear polarization until the lumen invasion, associated with a very low expression of the E-cadherin (Figures $1 \mathrm{C}$ and $2 \mathrm{~A}$ ), suggesting a different evolution of the disease in POU2F3-deficient mice, potentially linked to an increased epithelial-to-mesenchymal transition. 
A
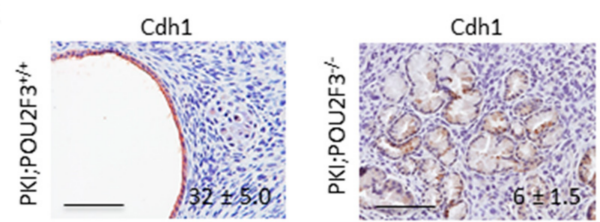

B

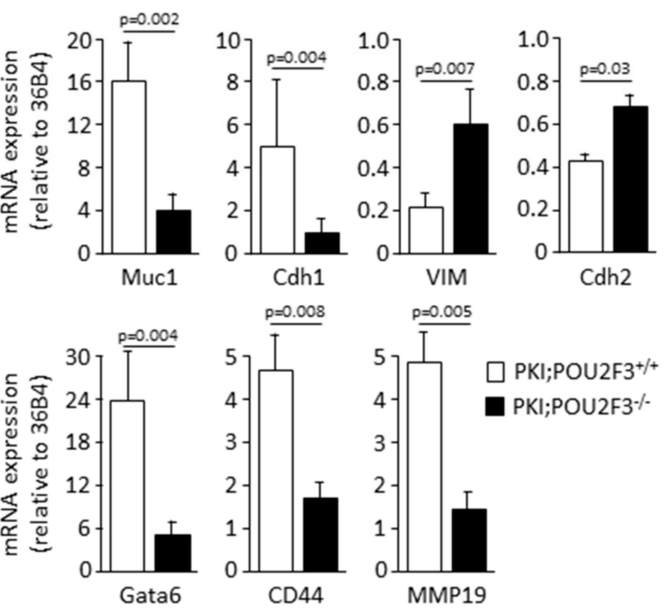

Figure 2. PDAC from PKI;POU2F3 $3^{-/}$mice is more differentiated. (A) Immuno-staining of Cdh1 in pancreas from $\mathrm{PKI} ; \mathrm{POU} 2 \mathrm{~F}^{+/+}$and $\mathrm{PKI} ; \mathrm{POU} 2 \mathrm{~F}^{-/-}$mice. Values denote positive cells per field. (B) mRNA expression in pancreas from PKI;POU2F3 ${ }^{+/+}$and PKI;POU2F3 mice. Scale set as $100 \mu \mathrm{m}$.

To address this hypothesis we measured the expression of several transcripts associated to the epithelial-to-mesenchymal transition by RT-qPCR as presented in Figure 2B. mRNA expression was calculated as relative to the $36 \mathrm{~B} 4 \mathrm{mRNA}$, a housekeeping ribosomal protein gene. Epithelial-associated markers such as Muc1 $(16.53 \pm 4.39$ vs. $4.84 \pm 1.97 ; p$-value $=0.002)$ and Cdh1 $(4.89 \pm 3.25$ vs. $2.23 \pm 1.08$; $p$-value $=0.004)$ were downregulated in PKI;POU2F3 ${ }^{-/-}$PDAC compared to PKI;POU2F3 ${ }^{+/+}$tumors. On the contrary, mesenchymal-associated markers like VIM ( $0.22 \pm 0.08$ vs. $0.59 \pm 0.31 ; p$-value $=0.007)$ and $\mathrm{Cdh} 2$, also known as $\mathrm{N}$-cadherin $(0.42 \pm 0.14$ vs. $0.64 \pm 0.28 ; p$-value $=0.03)$ were overexpressed in PKI;POU2F3 ${ }^{-/-}$PDAC compared to PKI;POU2F3 ${ }^{+/+}$tumors. Most importantly, GATA6, which is a marker of pancreatic differentiation and the main regulator of the classical PDAC subtype [34,35], was found 5 times higher in PDAC from PKI;POU2F3 ${ }^{+/+}(23.39 \pm 6.83$ vs. $5.12 \pm 3.02 ; p$-value $=0.004)$ as presented in Figure 2B, indicating that PDAC cells are less differentiated in POU2F3-deficient mice.

We also measured the expression of hyaluronic receptor CD44 [36] and metalloproteinase MMP19 [37] transcripts since they are associated to the metastatic potential of the PDAC. One is making bounds with the glycosaminoglycan while the other is degrading the proteins leading the way through the extracellular matrix. We found that these markers were overexpressed in PKI;POU2F3 ${ }^{+/+}$PDAC compared to PKI;POU2F3-/- tumors. CD44 and MMP19 expression were respectively $4.61 \pm 1.76 \mathrm{vs}$. $1.94 \pm 0.92 ; p$-value $=0.008$ and $4.65 \pm 1.64$ vs. $1.64 \pm 0.94 ; p$-value $=0.005$ (Figure $2 \mathrm{~B}$ ).

Altogether, these data strongly suggest that genetic inactivation of POU2F3 improves the epithelial-to-mesenchymal transition. Surprisingly, epithelial-to-mesenchymal transition is reported to be associated to the metastatic potential of the transformed cells. However, this process is higher in PKI;POU2F3 ${ }^{-/-}$tumors, they developed fewer liver metastases. Therefore, we can conclude that the enhanced epithelial-to-mesenchymal transition occurring in PKI;POU2F3 ${ }^{-/}$does not contribute to metastasis development.

\subsection{POU2F3 Inactivation Inhibits the Recruitment Inflammatory Mediators into the PDAC}

Since POU2F3 is an essential transcriptional factor for TUFT cells development and TUFT cells seems to play a major role in recruitment of inflammatory cells through the secretion of immunological 
factors, we studied the effect of POU2F3 deficiency on inflammation and immune cells recruitment in both PKI;POU2F3 ${ }^{+/+}$and PKI;POU2F3 ${ }^{-/-}$tumors. We observed the mRNA expression analyzed by RT-qPCR (Figure 3) or protein expression by immunohistochemistry (Figure 4) of several cytokines, chemokines and some of their receptors.
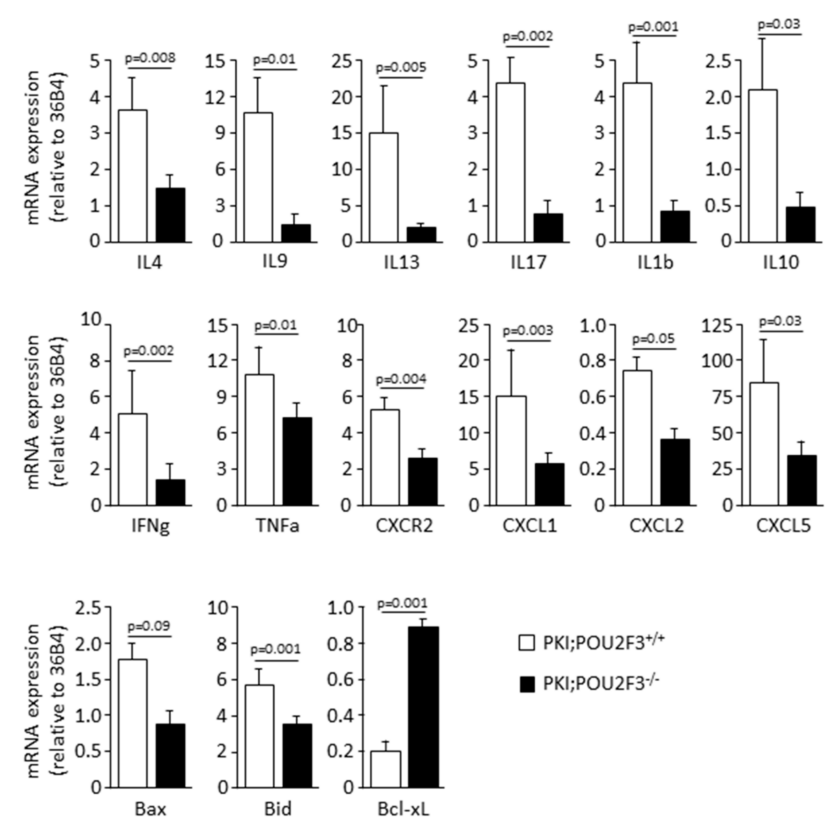

Figure 3. PDAC from PKI;POU2F3 $3^{-/}$mice express less level of inflammatory markers and overexpress anti-apototic markers. mRNA expression in pancreas from PKI;POU2F3 ${ }^{+/+}$and $\mathrm{PKI} ; \mathrm{POU} 2 \mathrm{~F} 3$ mice.
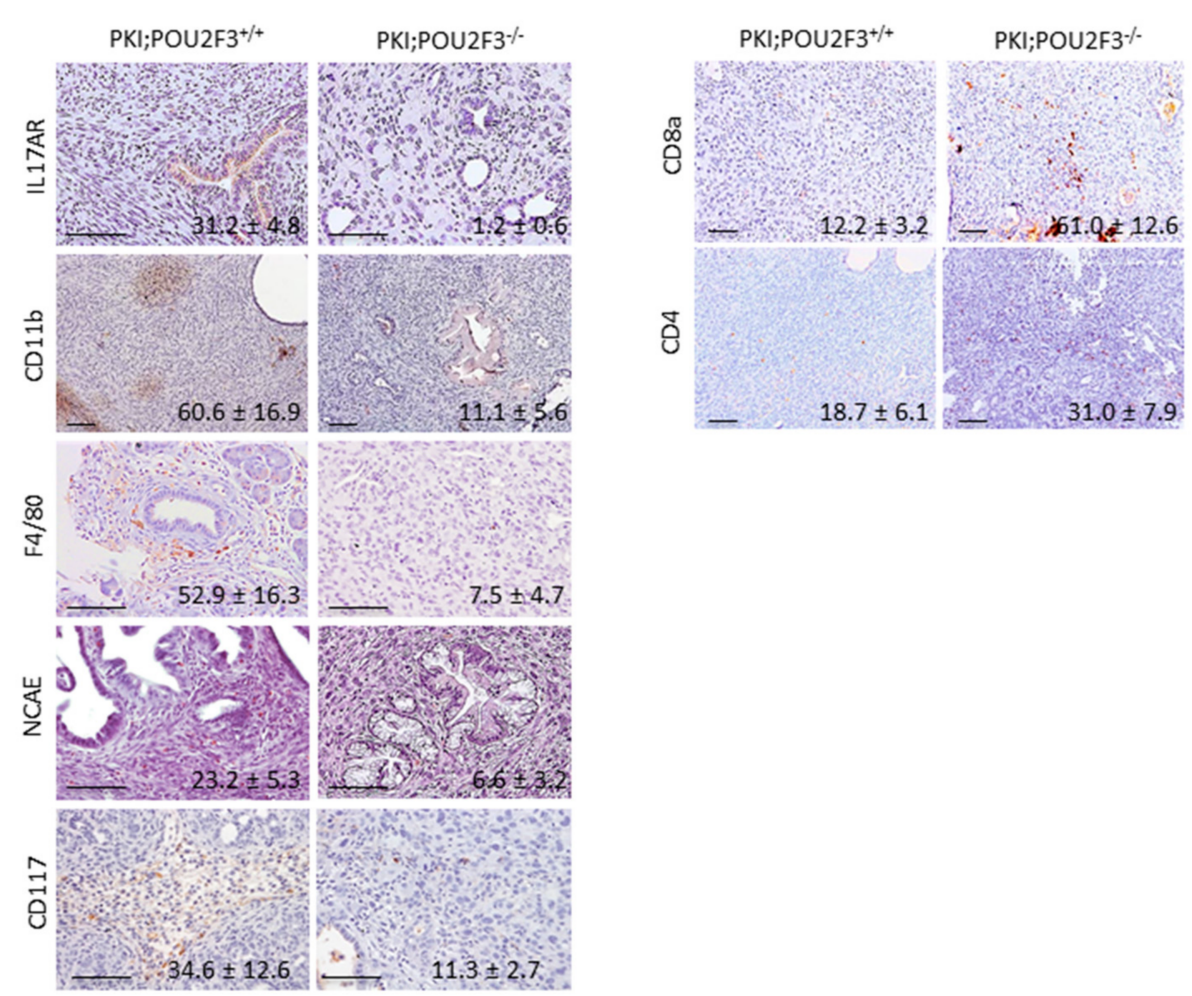

Figure 4. Immunological infiltration in PDAC. Immuno-staining of sections from pancreatic tumors. Values denote positive cells per field. Scale set as $100 \mu \mathrm{m}$. 
Histological staining of CD117-expressing cells also known as mast cells and associated with poor prognosis [38] shows a lower infiltration in PKI;POU2F3 ${ }^{-/-}$tumors for the benefits of CD4+ T-cells alongside CD8a-expressing cells that are more numerous regarding PKI;POU2F3 ${ }^{+/+}$sections. Among the stroma, we are actually counting numerous CD117-expressing cells in PKI;POU2 $\mathrm{F}^{+/+}$ sections regarding the PKI;POU2F3 ${ }^{-/-}$tissue $(34.6 \pm 12.6$ vs. $11.3 \pm 2.7$ cells; $p$-value $=0.01)$. In the opposite, we see a stronger staining targeting CD8a and CD4 in PKI;POU2F3 ${ }^{-/}$, mostly around the PanIN which are not that obvious in PKI;POU2F3 ${ }^{+/+}$tumors, (respectively $12.2 \pm 3.2$ vs. $61.0 \pm 12.6$ cells; $p$-value $=0.06$ and $18.7 \pm 6.1$ vs. $31.0 \pm 7.9$ cells; $p$-value $=0.05)$ as shown in Figure 4. Quantitative analysis of tumor RNA regarding specific cytokines for mast cells recruitment such as IL4 and IL9 confirmed our observations. Relative expression shown in Figure 4 is widely inferior in PKI;POU2F3 ${ }^{-/-}$ than PKI;POU2F3 ${ }^{+/+}$tissues (respectively $1.25 \pm 0.27$ vs. $3.68 \pm 1.58 ; p$-value $=0.008$ and $1.22 \pm 0.51$ vs. $10.12 \pm 4.93 ; p$-value $=0.01)$, just like IL13 $(0.90 \pm 0.14$ vs. $14.21 \pm 5.40 ; p$-value $=0.005)$ which is known to be stimulated by the TUFT cells [23] and determinant in the macrophages polarization [18]. Indeed, RNA analysis show higher expression of interleukin IL17A and IL1b (respectively $0.89 \pm 0.37$ vs. $4.35 \pm 0.61 ; p$-value $=0.002$ and $0.94 \pm 0.08$ vs. $4.28 \pm 1.86$; $p$-value $=0.001$ ) alongside the specific cytokines of inflammation IL10, IFNg and TNFa (respectively $0.42 \pm 0.13$ vs. $2.08 \pm 1.40$; $p$-value $=0.03$ and $1.43 \pm 0.92$ vs. $4.70 \pm 2.57 ; p$-value $=0.002$ and $6.55 \pm 1.09$ vs. $11.29 \pm 2.51 ; p$-value $=0.01$ ). All of those factors decreased when POU2F3 is knocked-out meaning that the inflammatory response is significantly impacted when TUFT cells are depleted.

Immuno-staining with anti-CD11b and anti-IL17R suggest that some leukocytes have been recruited on the tumoral site preferentially when POU2F3 is expressed (Figure 3). IL-17 is a proinflammatory cytokine that regulates both granulopoiesis and recruitment of neutrophils into sites of inflammation. This is due, in part, to the ability of IL-17A pathway to induce the release of CXC chemokines as well as to regulate the expression of G-CSF, a critical granulopoietic growth factor. Its receptor is known to play a pathogenic role in many inflammatory and autoimmune diseases [39] and seems to be expressed by the PanIN cells with basolateral localization in the PKI;POU2F3 ${ }^{+/+}$ tumors. Well, this is not observed in the PKI;POU2F3 ${ }^{-/-}$tumors. CD11b-expressing cells are definitely more present in the PKI;POU2F3 ${ }^{+/+}$tumors since we clearly see the infiltration among the stroma as foci at the edge of the high grade PanIN (Figure 4) as observed in the PKI;POU2F3 ${ }^{+/+}$pancreatic tumors (Figure 2A).

Precisely, typical marker of macrophages such as F4/80 helped us to characterize the polarization types that are present narrow those specific structures. It appears that the alternative is the activated macrophages, also known as M2, and pro-tumoral spread around the PanIN of PKI;POU2F3 ${ }^{+/+}$tumors and not in PKI;POU2F3 ${ }^{-1-}$. In the same way, enzymatic reaction shows the large contribution of neutrophils in PKI;POU2F3 ${ }^{+/+}$tumors only. Naphthol AS-D Chloro-Acetate Esterase (NCAE) has been proposed as a specific enzyme expressed in granulocytes lineage, but not in monocytes neither lymphocytes. The red color shows the presence of these cells in PKI;POU2F3 ${ }^{+/+}$tumors, once again around the high grade PanIN that are not observed in PKI;POU2F3 ${ }^{-/-}$. This is confirmed by the gene expression analysis of CXCR2 (Figure 4) $(2.86 \pm 0.67$ vs. $4.93 \pm 0.57 ; p$-value $=0.004)$ and chemokines responsible of their specific recruitment CXCL1 (Figure 4) $(5.11 \pm 2.01$ vs. $13.30 \pm 3.88 ; p$-value $=0.003)$, CXCL2 $(0.37 \pm 0.24$ vs. $0.77 \pm 0.10 ; p$-value $=0.05)$ and CXCL5 $(37.40 \pm 5.49$ vs. $79.03 \pm 36.50$; $p$-value $=0.03)$ which are all down-regulated in the absence of POU2F3.

Taken together, our results described both Tumor-Associated Neutrophiles (TAN) and Macrophages (TAM), characterizing the type 2 immune response alongside the mast cells [40]. Knocking out POU2F3 avoids the recruitment of such cells, reduces the inflammatory response and thus, apoptosis which is much more activated in the presence of TUFT cells. The expression of pro-apoptotic factors such as Bax and Bid are significantly higher in PKI;POU2F3 ${ }^{+/+}$tumors than PKI;POU2F3 ${ }^{-/-}$(Figure 3; respectively $0.92 \pm 0.35$ vs. $1.75 \pm 0.28$; $p$-value $=0.09$ and $3.86 \pm 0,41$ vs. $5.83 \pm 1.11 ; p$-value $=0.001)$. And in the opposite, mRNA of anti-apoptotic factor like Bcl-XL is more elevated in PKI;POU2F3 ${ }^{-/-}$tumors (Figure 4; $0.84 \pm 0.17$ vs. $0.22 \pm 0.06$; $p$-value $=0.001$ ). 
PKI;POU2F3 ${ }^{+/+}$tumors show a pro-apoptotic equilibrium while it is neutralized in PKI;POU2F3 ${ }^{-/-}$, reducing the call for immune cell income.

\subsection{Systemic POU2F3 Deficiency Has Minimal Effect on Immune Cells Populations}

POU2F3 is expressed in embryonic stem cells and the lineage related to the immune system such as thymocytes (CD4, CD8 and FoxP3 expressing cells), some antigen presenting cells (APC) like dendritic cells and also in granulocytes including neutrophils and mast cells [41]. We would assume that knocking out POU2F3 might have an effect on the global immune system development from the hematopoiesis that could explain the differences seen in the tumor adaptive response between PDAC of PKI;POU2F3 ${ }^{+/+}$and PKI;POU2F3 ${ }^{-/-}$mice.

No differences were observed in the spleen distribution regarding lymphoid and myeloid cells (Figure 5A) indicating that POU2F3 deletion does not impair hematopoiesis. We also screened cell populations harvested from the peritoneal cavity. We noticed in PKI;POU2F3 ${ }^{+/+}$as compare to PKI;POU2F3 ${ }^{-/}$mice a slight decrease of the Large Peritoneal Macrophages (LPM) for the benefit of Small Peritoneal Macrophages (SPM) expressing PD-L2 (Figure 5B). The marker CD8a (T lymphocytes and DC cells) was found not significantly different between both PKI;POU2F3 ${ }^{+/+}$and PKI;POU2F3 ${ }^{-/-}$ genotypes $(2.83 \pm 1.84$ vs. $2.26 \pm 0.66, p$-value $=0.2)$ and neither does the CD64 marker $(1.02 \pm 0.06$ vs. $1.33 \pm 0.34, p$-value $=0.02)$. Those data let us think that the adaptation of the immune response is probably triggered locally, on the tumor site, as a consequence of chemokine and/or cytokines production, such as IL13 instead of a direct effect on hematopoiesis.
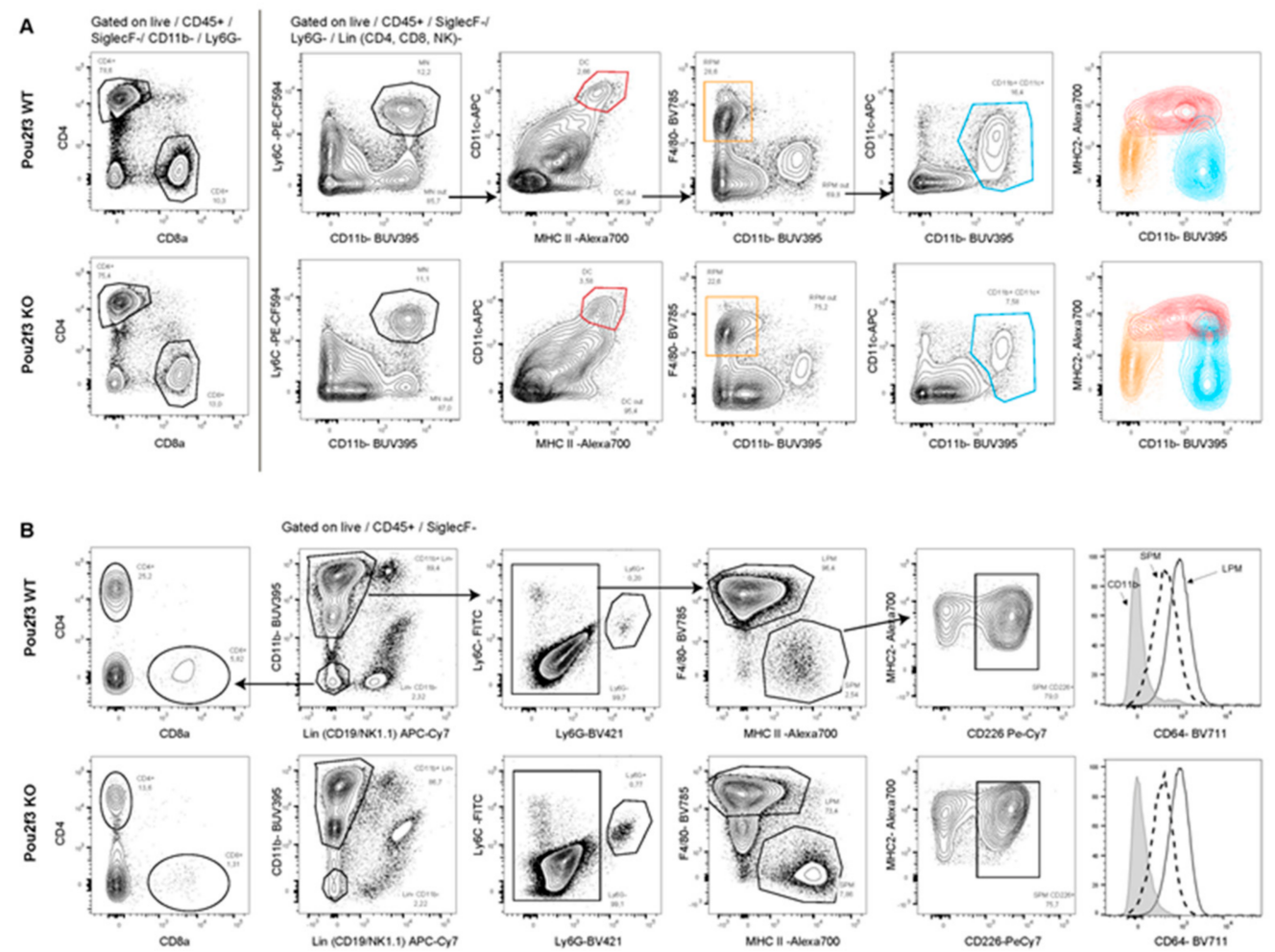

Figure 5. Immunophenotyping of cells from spleen and peritoneal cavity is similar in both genotypes. Cell sorting by flow cytometry of spleen cells (A) and from peritoneal cavity (B) from PKI;POU2F3 ${ }^{+/+}$ and PKI;POU2F3 ${ }^{-/-}$mice.

\section{Discussion}

In this work we showed that POU2F3 deletion in PKI mice model inhibits the TUFT cells development without any effect on the PDAC development and growth. Nevertheless, it increases the 
expression of the epithelial-to-mesenchymal transition markers, decreases the inflammatory response and inhibits the liver metastasis formation.

Presently, it is clear that PDAC development is the consequence of the progressive accumulation of genetic mutations occurring at every steps of the disease [42] with the combination of epigenetic [35] and transcriptomic alterations [43]. During the last years, scientist focused their interest on the microenvironment of PDAC which is wide and complex, making difficult any attempt for drug delivery and showing the cell communications through the large spectra of factors that are released helping cancer to grow and spread [44-48]. Mostly, the microenvironment composition in PDAC is heterogeneous and variable between patients $[43,49]$. Therefore, understanding the influence of the microenvironment composition is important to gain further improvements in the immunotherapies as a personal treatment.

TUFT cells express high level of DCLK1 protein which serves as a marker [22]. These cells are well-known to regulate inflammation and immune cells recruitment in some tissues [23]. Development of TUFT cells is dependent of the expression of the POU2F3 transcriptional factor since POU2F3 inactivation results in the absence of TUFT cells [23,24]. Therefore, POU2F3 inactivation serves as a model of TUFT depletion. In the PDAC developed in PKI;POU2F3 ${ }^{-/-}$mice we found a significant decrease of the inflammatory response involving cells (mast cells, macrophages and granulocytes), cytokines (IL4, IL9 and IL13, IL17a, IL1b, IL10, IFNg, TNFa) chemokines (CXCL1, CXCL2) and their receptors (IL17AR, CXCR2). On the contrary, we found an increase in T lymphocytes as identified as CD8a+ and CD4+ cells. Interestingly, we also found that expression of the pro-apoptotic factors Bax and Bid were repressed in POU2 $\mathrm{F}^{-/-}$mice, whereas the anti-apoptotic factor Bcl-XL was found overexpressed suggesting a lower apoptosis sensitivity in PDAC of POU2F3 ${ }^{-1-}$ mice. Altogether, these data show that, under a POU2F3-deficiency background, inflammation is strongly reduced and apoptotic sensitivity decreased. Another interesting, although unexpected, thing revealed in this work was that expression of markers of endothelial-to-mesenchymal transition (VIM and CDH2) were found increased in the PDAC from PKI/POU2F3 ${ }^{-/}$mice, whereas markers of epithelial cell differentiation (MUC, CDH1 and GATA6) were found decreased. Also, CD44 and the MMP19 molecules, which are involved in the metastatic process, were downregulated in POU2F3-deficient PDAC. These data indicate that POU2F3 inactivation, through a still unexplained molecular mechanism, influences the endothelial-to-mesenchymal transition. Despite every expectation, although endothelial-to-mesenchymal transition was stronger in PKI/POU2F3 ${ }^{-1}$ mice these animals presented less liver metastasis. Taken together, our work reveals that metastasis could be the direct consequences of the immune response driven by inflammation and/or apoptosis for the recruitment of $\mathrm{T}$ lymphocytes instead of the endothelial-to-mesenchymal transition process.

\section{Conclusions}

Since, POU2F3 expression may influences expansion of some components of the inflammatory and immune system we analyzed the cell populations in spleen and peritoneal cavity distribution by flow cytometry. Our results have shown that only minor differences were detected between POU2F3 deficient or proficient mice. This approach allowed us to show that the inflammatory and immune response observed in PDAC from POU2F3 deficient mice has been triggered directly from the tumor site and not through some alterations of the hematopoiesis. We hypothesize that TUFT cells, which are known to modulate the recruitment of inflammatory and immune cells, are at the origin of these differences.

Supplementary Materials: The following are available online at http://www.mdpi.com/2079-7737/9/10/341/s1. Supplementary Table S1. Antibodies; Supplementary Table S2. Primers and Supplementary Table S3. Primary antibodies for Flow Cytometer analysis

Author Contributions: Conceptualization, J.I. and P.J.; methodology, J.B., A.M.A., F.G., E.S., P.J. and J.I.; formal analysis, J.B., A.M.A., E.B., N.A.-A., E.S. and J.I.; investigation, J.B., A.M.A., E.B. and N.A.-A.; resources, P.J. and J.I.; writing-original draft preparation, J.B., P.J. and J.I.; writing—review and editing, A.M.A., P.J. and J.I.; supervision, 
P.J. and J.I.; project administration, P.J. and J.I.; funding acquisition, P.J. and J.I. All authors have read and agreed to the published version of the manuscript.

Funding: This research was funded by La Ligue Contre le Cancer, INCa, Canceropole PACA, DGOS (labellisation SIRIC) and INSERM.

Conflicts of Interest: The authors declare no conflict of interest. The funders had no role in the design of the study; in the collection, analyses, or interpretation of data; in the writing of the manuscript, or in the decision to publish the results.

\section{References}

1. Du, T.; Bill, K.A.; Ford, J.; Barawi, M.; Hayward, R.D.; Alame, A.; Berri, R.N. The diagnosis and staging of pancreatic cancer: A comparison of endoscopic ultrasound and computed tomography with pancreas protocol. Am. J. Surg. 2018, 215, 472-475. [CrossRef] [PubMed]

2. Grasso, C.; Jansen, G.; Giovannetti, E. Drug resistance in pancreatic cancer: Impact of altered energy metabolism. Crit. Rev. Oncol. Hematol. 2017, 114, 139-152. [CrossRef]

3. Lee, B.; Hutchinson, R.; Wong, H.L.; Tie, J.; Putoczki, T.; Tran, B.; Gibbs, P.; Christie, M. Emerging biomarkers for immunomodulatory cancer treatment of upper gastrointestinal, pancreatic and hepatic cancers. Semin. Cancer Biol. 2017. [CrossRef]

4. Varghese, A.M. Chimeric antigen receptor (CAR) T and other $\mathrm{T}$ cell strategies for pancreas adenocarcinoma. Chin. Clin. Oncol. 2017, 6, 66. [CrossRef] [PubMed]

5. Reck, M.; Rabe, K.F. Precision Diagnosis and Treatment for Advanced Non-Small-Cell Lung Cancer. N. Engl. J. Med. 2017, 377, 849-861. [CrossRef] [PubMed]

6. Eggermont, A.M.; Spatz, A.; Robert, C. Cutaneous melanoma. Lancet 2014, 383, 816-827. [CrossRef]

7. Aoun, F.; Kourie, H.R.; Sideris, S.; Roumeguere, T.; van Velthoven, R.; Gil, T. Checkpoint inhibitors in bladder and renal cancers: Results and perspectives. Immunotherapy 2015, 7, 1259-1271. [CrossRef]

8. Wada, K.; Takaori, K.; Traverso, L.W. Screening for Pancreatic Cancer. Surg. Clin. N. Am. 2015, 95, 1041-1052. [CrossRef]

9. Beuran, M.; Negoi, I.; Paun, S.; Ion, A.D.; Bleotu, C.; Negoi, R.I.; Hostiuc, S. The epithelial to mesenchymal transition in pancreatic cancer: A systematic review. Pancreatol. Off. J. Int. Assoc. Pancreatol. 2015, 15, 217-225. [CrossRef]

10. Tang, D.; Wang, D.; Yuan, Z.; Xue, X.; Zhang, Y.; An, Y.; Chen, J.; Tu, M.; Lu, Z.; Wei, J.; et al. Persistent activation of pancreatic stellate cells creates a microenvironment favorable for the malignant behavior of pancreatic ductal adenocarcinoma. Int. J. Cancer 2013, 132, 993-1003. [CrossRef]

11. Achyut, B.R.; Yang, L. Transforming growth factor-beta in the gastrointestinal and hepatic tumor microenvironment. Gastroenterology 2011, 141, 1167-1178. [CrossRef] [PubMed]

12. Beauchemin, N.; Arabzadeh, A. Carcinoembryonic antigen-related cell adhesion molecules (CEACAMs) in cancer progression and metastasis. Cancer Metastasis Rev. 2013, 32, 643-671. [CrossRef] [PubMed]

13. Knapinska, A.M.; Estrada, C.A.; Fields, G.B. The Roles of Matrix Metalloproteinases in Pancreatic Cancer. Prog. Mol. Biol. Transl. Sci. 2017, 148, 339-354. [CrossRef]

14. Hamada, S.; Masamune, A.; Shimosegawa, T. Inflammation and pancreatic cancer: Disease promoter and new therapeutic target. J. Gastroenterol. 2014, 49, 605-617. [CrossRef] [PubMed]

15. Steele, C.W.; Jamieson, N.B.; Evans, T.R.; McKay, C.J.; Sansom, O.J.; Morton, J.P.; Carter, C.R. Exploiting inflammation for therapeutic gain in pancreatic cancer. Br. J. Cancer 2013, 108, 997-1003. [CrossRef]

16. Guerra, C.; Schuhmacher, A.J.; Canamero, M.; Grippo, P.J.; Verdaguer, L.; Perez-Gallego, L.; Dubus, P.; Sandgren, E.P.; Barbacid, M. Chronic pancreatitis is essential for induction of pancreatic ductal adenocarcinoma by K-Ras oncogenes in adult mice. Cancer Cell 2007, 11, 291-302. [CrossRef]

17. Guerra, C.; Collado, M.; Navas, C.; Schuhmacher, A.J.; Hernandez-Porras, I.; Canamero, M.; Rodriguez-Justo, M.; Serrano, M.; Barbacid, M. Pancreatitis-induced inflammation contributes to pancreatic cancer by inhibiting oncogene-induced senescence. Cancer Cell 2011, 19, 728-739. [CrossRef]

18. Gerbe, F.; Legraverend, C.; Jay, P. The intestinal epithelium tuft cells: Specification and function. Cell. Mol. Life Sci. CMLS 2012, 69, 2907-2917. [CrossRef] 
19. Gerbe, F.; van Es, J.H.; Makrini, L.; Brulin, B.; Mellitzer, G.; Robine, S.; Romagnolo, B.; Shroyer, N.F.; Bourgaux, J.F.; Pignodel, C.; et al. Distinct ATOH1 and Neurog3 requirements define tuft cells as a new secretory cell type in the intestinal epithelium. J. Cell Biol. 2011, 192, 767-780. [CrossRef]

20. Liou, G.Y.; Bastea, L.; Fleming, A.; Doppler, H.; Edenfield, B.H.; Dawson, D.W.; Zhang, L.; Bardeesy, N.; Storz, P. The Presence of Interleukin-13 at Pancreatic ADM/PanIN Lesions Alters Macrophage Populations and Mediates Pancreatic Tumorigenesis. Cell Rep. 2017, 19, 1322-1333. [CrossRef]

21. DelGiorno, K.E.; Chung, C.Y.; Vavinskaya, V.; Maurer, H.C.; Novak, S.W.; Lytle, N.K.; Ma, Z.; Giraddi, R.R.; Wang, D.; Fang, L.; et al. Tuft Cells Inhibit Pancreatic Tumorigenesis in Mice by Producing Prostaglandin D2. Gastroenterology 2020. [CrossRef] [PubMed]

22. Saqui-Salces, M.; Keeley, T.M.; Grosse, A.S.; Qiao, X.T.; El-Zaatari, M.; Gumucio, D.L.; Samuelson, L.C.; Merchant, J.L. Gastric tuft cells express DCLK1 and are expanded in hyperplasia. Histochem. Cell Biol. 2011, 136, 191-204. [CrossRef] [PubMed]

23. Gerbe, F.; Sidot, E.; Smyth, D.J.; Ohmoto, M.; Matsumoto, I.; Dardalhon, V.; Cesses, P.; Garnier, L.; Pouzolles, M.; Brulin, B.; et al. Intestinal epithelial tuft cells initiate type 2 mucosal immunity to helminth parasites. Nature 2016, 529, 226-230. [CrossRef]

24. Huang, Y.H.; Klingbeil, O.; He, X.Y.; Wu, X.S.; Arun, G.; Lu, B.; Somerville, T.D.D.; Milazzo, J.P.; Wilkinson, J.E.; Demerdash, O.E.; et al. POU2F3 is a master regulator of a tuft cell-like variant of small cell lung cancer. Genes Dev. 2018, 32, 915-928. [CrossRef] [PubMed]

25. Westphalen, C.B.; Takemoto, Y.; Tanaka, T.; Macchini, M.; Jiang, Z.; Renz, B.W.; Chen, X.; Ormanns, S.; Nagar, K.; Tailor, Y.; et al. Dclk1 Defines Quiescent Pancreatic Progenitors that Promote Injury-Induced Regeneration and Tumorigenesis. Cell Stem Cell 2016, 18, 441-455. [CrossRef] [PubMed]

26. Ito, H.; Tanaka, S.; Akiyama, Y.; Shimada, S.; Adikrisna, R.; Matsumura, S.; Aihara, A.; Mitsunori, Y.; Ban, D.; Ochiai, T.; et al. Dominant Expression of DCLK1 in Human Pancreatic Cancer Stem Cells Accelerates Tumor Invasion and Metastasis. PLoS ONE 2016, 11, e0146564. [CrossRef] [PubMed]

27. Bailey, J.M.; Alsina, J.; Rasheed, Z.A.; McAllister, F.M.; Fu, Y.Y.; Plentz, R.; Zhang, H.; Pasricha, P.J.; Bardeesy, N.; Matsui, W.; et al. DCLK1 marks a morphologically distinct subpopulation of cells with stem cell properties in preinvasive pancreatic cancer. Gastroenterology 2014, 146, 245-256. [CrossRef] [PubMed]

28. Sureban, S.M.; May, R.; Qu, D.; Weygant, N.; Chandrakesan, P.; Ali, N.; Lightfoot, S.A.; Pantazis, P.; Rao, C.V.; Postier, R.G.; et al. DCLK1 regulates pluripotency and angiogenic factors via microRNA-dependent mechanisms in pancreatic cancer. PLoS ONE 2013, 8, e73940. [CrossRef]

29. Sureban, S.M.; May, R.; Lightfoot, S.A.; Hoskins, A.B.; Lerner, M.; Brackett, D.J.; Postier, R.G.; Ramanujam, R.; Mohammed, A.; Rao, C.V.; et al. DCAMKL-1 regulates epithelial-mesenchymal transition in human pancreatic cells through a miR-200a-dependent mechanism. Cancer Res. 2011, 71, 2328-2338. [CrossRef]

30. Cano, C.E.; Hamidi, T.; Garcia, M.N.; Grasso, D.; Loncle, C.; Garcia, S.; Calvo, E.; Lomberk, G.; Dusetti, N.; Bartholin, L.; et al. Genetic inactivation of Nupr1 acts as a dominant suppressor event in a two-hit model of pancreatic carcinogenesis. Gut 2014, 63, 984-995. [CrossRef]

31. Gu, G.; Dubauskaite, J.; Melton, D.A. Direct evidence for the pancreatic lineage: NGN3+ cells are islet progenitors and are distinct from duct progenitors. Development 2002, 129, 2447-2457. [PubMed]

32. Aguirre, A.J.; Bardeesy, N.; Sinha, M.; Lopez, L.; Tuveson, D.A.; Horner, J.; Redston, M.S.; DePinho, R.A. Activated Kras and Ink4a/Arf deficiency cooperate to produce metastatic pancreatic ductal adenocarcinoma. Genes Dev. 2003, 17, 3112-3126. [CrossRef] [PubMed]

33. Bardeesy, N.; Aguirre, A.J.; Chu, G.C.; Cheng, K.H.; Lopez, L.V.; Hezel, A.F.; Feng, B.; Brennan, C.; Weissleder, R.; Mahmood, U.; et al. Both p16(Ink4a) and the p19(Arf)-p53 pathway constrain progression of pancreatic adenocarcinoma in the mouse. Proc. Natl. Acad. Sci. USA 2006, 103, 5947-5952. [CrossRef] [PubMed]

34. Martinelli, P.; Carrillo-de Santa Pau, E.; Cox, T.; Sainz, B., Jr.; Dusetti, N.; Greenhalf, W.; Rinaldi, L.; Costello, E.; Ghaneh, P.; Malats, N.; et al. GATA6 regulates EMT and tumour dissemination, and is a marker of response to adjuvant chemotherapy in pancreatic cancer. Gut 2017, 66, 1665-1676. [CrossRef] [PubMed]

35. Lomberk, G.; Blum, Y.; Nicolle, R.; Nair, A.; Gaonkar, K.S.; Marisa, L.; Mathison, A.; Sun, Z.; Yan, H.; Elarouci, N.; et al. Distinct epigenetic landscapes underlie the pathobiology of pancreatic cancer subtypes. Nat. Commun. 2018, 9, 1978. [CrossRef] [PubMed]

36. Zeng, L.; Chen, Y.; Chen, L.; Tang, C. Prognostic value of CD44v9 expression in human cancers: A systematic review and meta-analysis. Medicine 2020, 99, e20428. [CrossRef] [PubMed] 
37. Chen, Z.; Wu, G.; Ye, F.; Chen, G.; Fan, Q.; Dong, H.; Zhu, X.; Wu, C. High expression of MMP19 is associated with poor prognosis in patients with colorectal cancer. BMC Cancer 2019, 19, 448. [CrossRef] [PubMed]

38. Fan, H.; Yuan, Y.; Wang, J.; Zhou, F.; Zhang, M.; Giercksky, K.E.; Nesland, J.M.; Suo, Z. CD117 expression in operable oesophageal squamous cell carcinomas predicts worse clinical outcome. Histopathology 2013, 62, 1028-1037. [CrossRef]

39. Zhang, Y.; Zoltan, M.; Riquelme, E.; Xu, H.; Sahin, I.; Castro-Pando, S.; Montiel, M.F.; Chang, K.; Jiang, Z.; Ling, J.; et al. Immune Cell Production of Interleukin 17 Induces Stem Cell Features of Pancreatic Intraepithelial Neoplasia Cells. Gastroenterology 2018, 155, 210-223.e213. [CrossRef]

40. Inman, K.S.; Francis, A.A.; Murray, N.R. Complex role for the immune system in initiation and progression of pancreatic cancer. World J. Gastroenterol. 2014, 20, 11160-11181. [CrossRef]

41. Yukawa, K.; Yasui, T.; Yamamoto, A.; Shiku, H.; Kishimoto, T.; Kikutani, H. Epoc-1: A POU-domain gene expressed in murine epidermal basal cells and thymic stromal cells. Gene 1993, 133, 163-169.

42. Notta, F.; Hahn, S.A.; Real, F.X. A genetic roadmap of pancreatic cancer: Still evolving. Gut 2017, 66, 2170-2178. [CrossRef] [PubMed]

43. Nicolle, R.; Blum, Y.; Marisa, L.; Loncle, C.; Gayet, O.; Moutardier, V.; Turrini, O.; Giovannini, M.; Bian, B.; Bigonnet, M.; et al. Pancreatic Adenocarcinoma Therapeutic Targets Revealed by Tumor-Stroma Cross-Talk Analyses in Patient-Derived Xenografts. Cell Rep. 2017, 21, 2458-2470. [CrossRef] [PubMed]

44. Ahn, D.H.; Ramanathan, R.K. Targeting the stroma in pancreatic cancer. Chin. Clin. Oncol. 2017, 6, 65. [CrossRef]

45. Iovanna, J.L.; Closa, D. Factors released by the tumor far microenvironment are decisive for pancreatic adenocarcinoma development and progression. Oncoimmunology 2017, 6, e1358840. [CrossRef]

46. Vennin, C.; Murphy, K.J.; Morton, J.P.; Cox, T.R.; Pajic, M.; Timpson, P. Reshaping the Tumor Stroma for Treatment of Pancreatic Cancer. Gastroenterology 2018, 154, 820-838. [CrossRef] [PubMed]

47. Argentiero, A.; De Summa, S.; Di Fonte, R.; Iacobazzi, R.M.; Porcelli, L.; Da Via, M.; Brunetti, O.; Azzariti, A.; Silvestris, N.; Solimando, A.G. Gene Expression Comparison between the Lymph Node-Positive and -Negative Reveals a Peculiar Immune Microenvironment Signature and a Theranostic Role for WNT Targeting in Pancreatic Ductal Adenocarcinoma: A Pilot Study. Cancers 2019, 11. [CrossRef]

48. Porcelli, L.; Iacobazzi, R.M.; Di Fonte, R.; Serrati, S.; Intini, A.; Solimando, A.G.; Brunetti, O.; Calabrese, A.; Leonetti, F.; Azzariti, A.; et al. CAFs and TGF-beta Signaling Activation by Mast Cells Contribute to Resistance to Gemcitabine/Nabpaclitaxel in Pancreatic Cancer. Cancers 2019, 11. [CrossRef]

49. Moffitt, R.A.; Marayati, R.; Flate, E.L.; Volmar, K.E.; Loeza, S.G.; Hoadley, K.A.; Rashid, N.U.; Williams, L.A.; Eaton, S.C.; Chung, A.H.; et al. Virtual microdissection identifies distinct tumor- and stroma-specific subtypes of pancreatic ductal adenocarcinoma. Nat. Genet. 2015, 47, 1168-1178. [CrossRef]

Publisher's Note: MDPI stays neutral with regard to jurisdictional claims in published maps and institutional affiliations.

(C) 2020 by the authors. Licensee MDPI, Basel, Switzerland. This article is an open access article distributed under the terms and conditions of the Creative Commons Attribution (CC BY) license (http://creativecommons.org/licenses/by/4.0/). 